\title{
Dissolved organic carbon (DOC) in Arctic ground ice
}

\author{
M. Fritz ${ }^{1}$, T. Opel ${ }^{1}$, G. Tanski ${ }^{1}$, U. Herzschuh ${ }^{1,2}$, H. Meyer ${ }^{1}$, A. Eulenburg ${ }^{1}$, and H. Lantuit ${ }^{1,2}$ \\ ${ }^{1}$ Alfred Wegener Institute Helmholtz Centre for Polar and Marine Research, Department of Periglacial Research, \\ Potsdam, Germany \\ ${ }^{2}$ University of Potsdam, Institute of Earth and Environmental Sciences, Potsdam, Germany \\ Correspondence to: M. Fritz (michael.fritz@awi.de)
}

Received: 5 November 2014 - Published in The Cryosphere Discuss.: 7 January 2015

Revised: 26 March 2015 - Accepted: 26 March 2015 - Published: 20 April 2015

\begin{abstract}
Thermal permafrost degradation and coastal erosion in the Arctic remobilize substantial amounts of organic carbon (OC) and nutrients which have accumulated in late Pleistocene and Holocene unconsolidated deposits. Permafrost vulnerability to thaw subsidence, collapsing coastlines and irreversible landscape change are largely due to the presence of large amounts of massive ground ice such as ice wedges. However, ground ice has not, until now, been considered to be a source of dissolved organic carbon (DOC), dissolved inorganic carbon (DIC) and other elements which are important for ecosystems and carbon cycling. Here we show, using biogeochemical data from a large number of different ice bodies throughout the Arctic, that ice wedges have the greatest potential for DOC storage, with a maximum of $28.6 \mathrm{mg} \mathrm{L}^{-1}$ (mean: $9.6 \mathrm{mg} \mathrm{L}^{-1}$ ). Variation in DOC concentration is positively correlated with and explained by the concentrations and relative amounts of typically terrestrial cations such as $\mathrm{Mg}^{2+}$ and $\mathrm{K}^{+}$. DOC sequestration into ground ice was more effective during the late Pleistocene than during the Holocene, which can be explained by rapid sediment and OC accumulation, the prevalence of more easily degradable vegetation and immediate incorporation into permafrost. We assume that pristine snowmelt is able to leach considerable amounts of well-preserved and highly bioavailable DOC as well as other elements from surface sediments, which are rapidly frozen and stored in ground ice, especially in ice wedges, even before further degradation. We found that ice wedges in the Yedoma region represent a significant DOC $(45.2 \mathrm{Tg})$ and DIC (33.6 Tg) pool in permafrost areas and a freshwater reservoir of $4200 \mathrm{~km}^{2}$. This study underlines the need to discriminate between particulate $\mathrm{OC}$ and DOC to assess the availability and vulnerability of the permafrost car-
\end{abstract}

bon pool for ecosystems and climate feedback upon mobilization.

\section{Introduction}

Vast parts of the coastal lowlands of Siberia, Alaska and Canada consist of unconsolidated organic-rich, fine-grained deposits. These sediments, which occur as glacigenic and Yedoma-type sediments (including their degradation forms as thermokarst), are characterized by high ground-ice contents, both on a volumetric (vol\%) and gravimetric (wt \%) basis (Brown et al., 1997; Zhang et al., 1999; Grosse et al., 2013; Schirrmeister et al., 2013). Yedoma deposits, which formed during the late Pleistocene cold stages in unglaciated Beringia (Schirrmeister et al., 2013), for instance, are characterized by absolute ground-ice contents, excluding ice wedges, of 40-60 wt \% (Schirrmeister et al., 2011c). Ice wedges are one of the most common types of ground ice in permafrost. They form when thermal contraction cracks open in winter, which are periodically filled with snow meltwater in spring that quickly (re)freezes at negative ground temperatures to form ice veins and finally vertically foliated ice wedges. The ice wedges are themselves characterized by volumetric ice contents approaching $100 \mathrm{vol} \%$ and make up much of the subsurface in these Yedoma deposits. Recent calculations of ice-wedge volumes in east Siberian Pleistocene Yedoma and Holocene thermokarst deposits show contents of 48 and $7 \mathrm{vol} \%$, respectively (Strauss et al., 2013). Combining ice wedges and other ice types in Yedoma deposits gives a mean volumetric ground-ice content for those regions between 60 and 82 vol \% (Zimov et al., 2006a, b; Schirrmeister et al., 2011b, c; Strauss et al., 2013). High ground-ice 
contents are also typical for coastal Alaska (43-89 vol \%; Kanevskiy et al., 2011, 2013) and the western Canadian Arctic (50-60 vol \%; French, 1998). The presence of massive ice (i.e., gravimetric ice content $>250 \%$ on dry soil weight basis; cf. van Everdingen, 1998) and excess ice, which is visible ice that exceeds the pore space, is the key factor for the vulnerability of permafrost to warmer temperatures and mechanical disturbance, as ice melt will initiate surface subsidence and thermal collapse, also known as thermokarst (Czudek and Demek, 1970).

Permafrost soils hold approximately $50 \%$ of the global soil carbon pool (Tarnocai et al., 2009; Hugelius et al., 2014), mostly as particulate organic carbon (POC). These calculations of permafrost OC stocks, however, subtract the groundice content (Zimov et al., 2006a, b; Tarnocai et al., 2009; Strauss et al., 2013; Hugelius et al., 2013, 2014) and therefore disregard the OC, especially the amount of dissolved organic carbon (DOC), contained in large ground-ice bodies such as ice wedges and other types of massive ice. Although these numbers might be small compared to the POC stocks in peat and mineral soils, DOC from permafrost is chemically labile (Dou et al., 2008; Vonk et al., 2013a, b) and may directly enter local food webs. Due to its lability, DOC can become quickly mineralized by microbial communities and photochemical reactions (Battin et al., 2008; Vonk et al., 2013a, b; Cory et al., 2014) and returned to the atmosphere when released due to permafrost degradation (Schuur et al., 2009; Schuur and Abbot, 2011).

Several studies have shed light on the POC stocks contained in permafrost (e.g., Zimov et al., 2006a; Tarnocai et al., 2009; Schirrmeister et al., 2011b; Strauss et al., 2013; Hugelius et al., 2013, 2014; Walter Anthony et al., 2014) and how much of these stocks is potentially mobilized due to thermal permafrost degradation and coastal erosion (Rachold et al., 2004; Jorgenson and Brown, 2005; Lantuit et al., 2009; McGuire et al., 2009; Ping et al., 2011; Schneider von Deimling et al., 2012; Vonk et al., 2012; Günther et al., 2013, 2015; Wegner et al., 2015). DOC fluxes have also been quantified in western Siberian catchments (Frey and Smith, 2005), and monitoring efforts of the large rivers draining permafrost areas and entering into the Arctic Ocean have provided robust estimations of the riverine DOC export (Raymond et al., 2007; McGuire et al., 2009). However, DOC stocks in permafrost ground ice and the resulting potential DOC fluxes in response to coastal erosion and thermal degradation are still unknown (Guo et al., 2007; Duo et al., 2008). At this moment, any inference about DOC stocks in permafrost and fluxes from permafrost is derived from measurements in secondary systems such as lake (e.g., Kling et al., 1991; Walter Anthony et al., 2014), river (e.g., Benner et al., 2004; Finlay et al., 2006; Guo et al., 2007; Raymond et al., 2007; Holmes et al., 2012) and ocean waters (e.g., Opsahl and Benner, 1997; Dittmar and Kattner; 2003; Cooper et al., 2005) or from laboratory experiments (Dou et al., 2008). In contrast, the purpose of this study was to sample and measure DOC

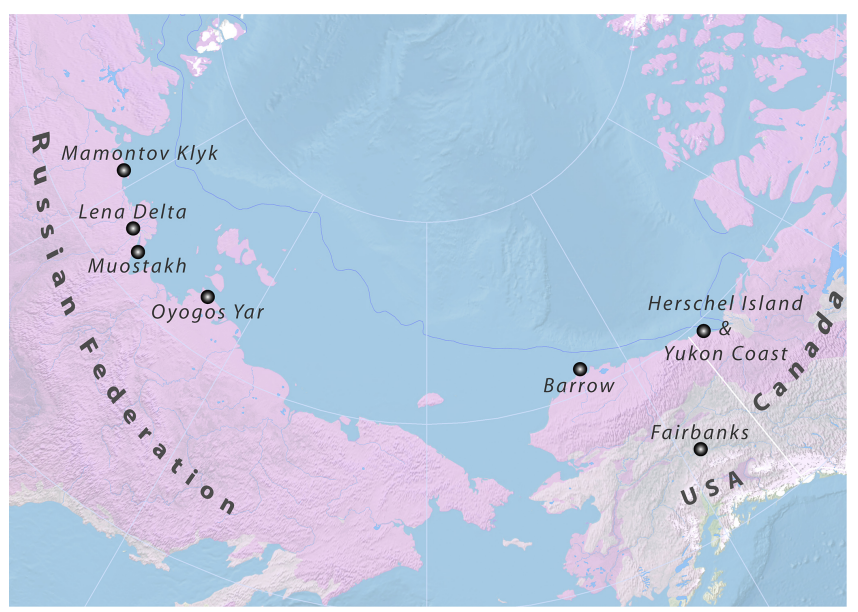

Figure 1. Study area and study sites (dots) for massive groundice sampling in the Arctic lowlands of Siberia and North America. All study sites are located within the zone of continuous permafrost (dark purple), except for the Fairbanks area, which is the zone of discontinuous permafrost (light purple). Blue line in the Arctic Ocean marks the northerly extent of submarine permafrost according to Brown et al. (1997).

at the source (i.e., ground ice in permafrost) directly, before it gets altered by natural processes such as exposure to the atmosphere, lithosphere and hydrosphere.

Here, we present an Arctic-wide study on DOC stocks in ground ice, aiming at incorporating massive ground ice into the Arctic permafrost carbon budget. The specific objectives of our study are

- to quantify DOC contents in different massive groundice types;

- to calculate DOC stocks in massive ground ice at the Arctic level;

- to put ground-ice-related DOC stocks into the context of the terrestrial Arctic OC pools and fluxes;

- to introduce relationships between organic and inorganic geochemical parameters, stable water isotopes, stratigraphy, and genetic and spatial characteristics to shed light on the origin of DOC and the processes of carbon sequestration in ground ice.

\section{Study area and study sites}

This study was carried out along the coastal lowlands of east Siberia, Alaska and northwest Canada (Fig. 1). All study sites, except for the Fairbanks area, are located within the zone of continuous permafrost. The sites cover a wide and representative range of geomorphological settings, terrain units and ground-ice conditions (Table 1). All studied ground-ice bodies were found in ice-rich unconsolidated 


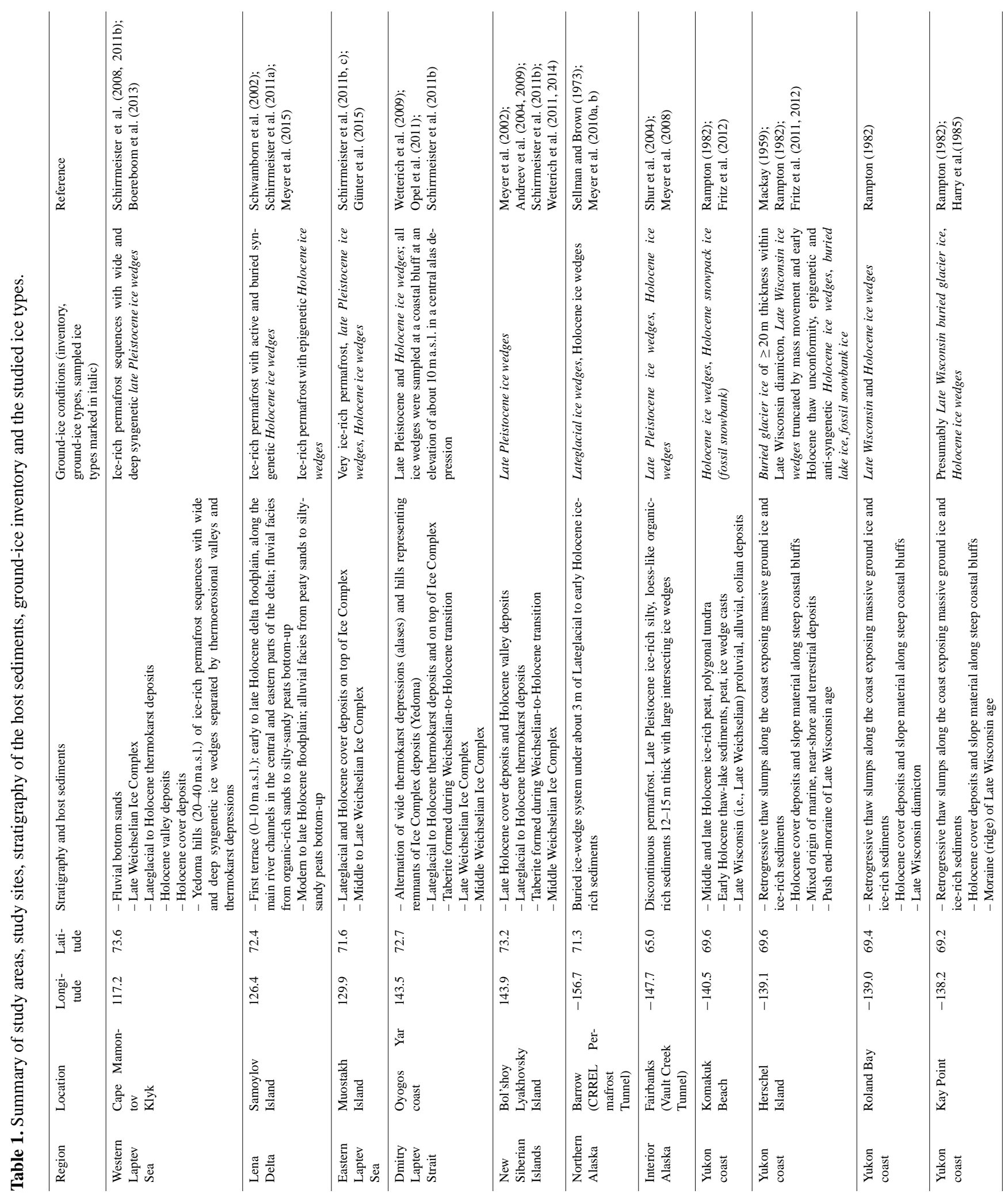



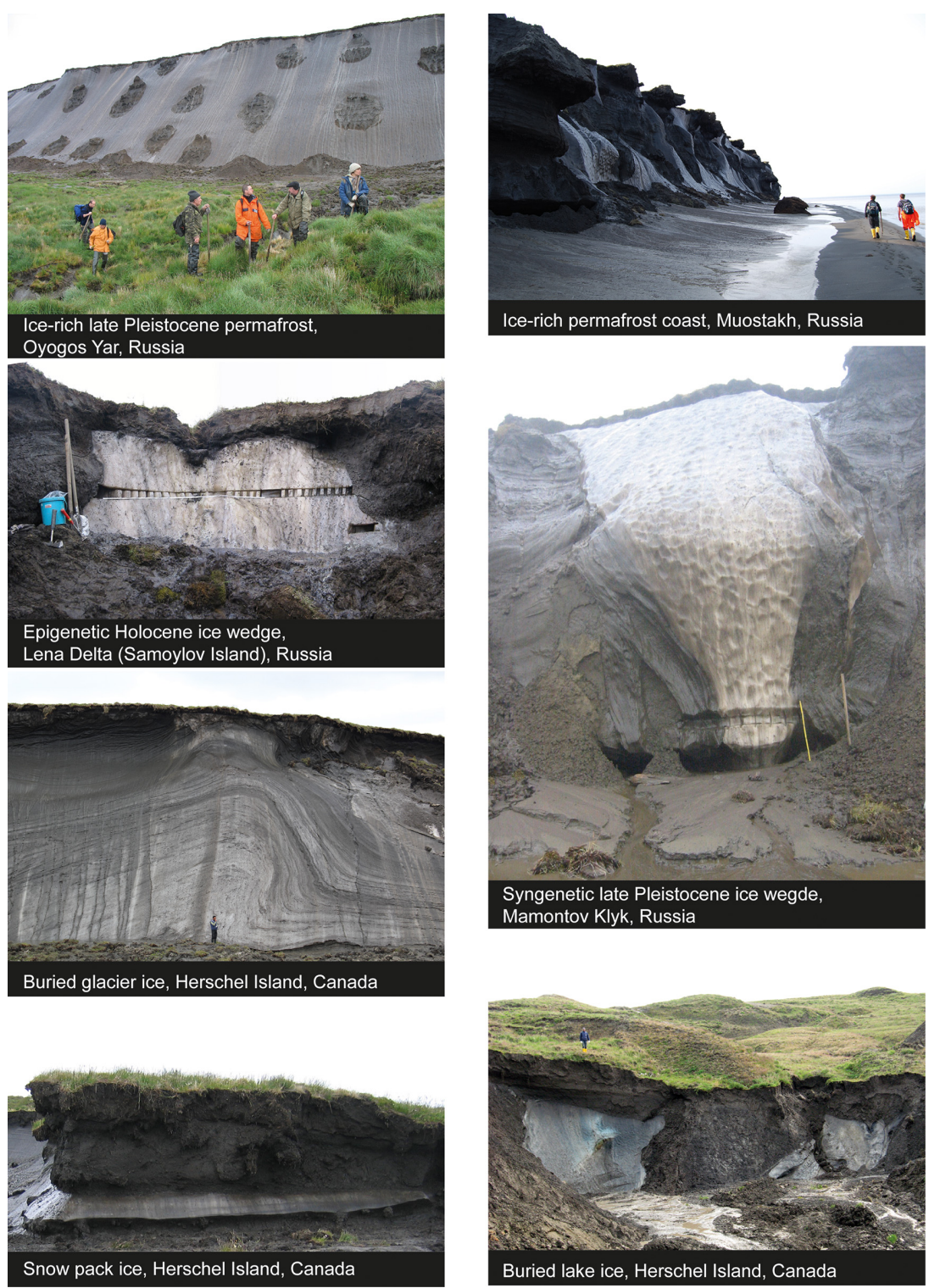

Figure 2. Ground-ice conditions and examples of studied ground-ice types in the Siberian and North American Arctic. Place names are plotted on Fig. 1.

Holocene and late Pleistocene (Marine Isotope Stages 2-5) deposits. Outcrops in permafrost either were accessible due to strong rates of coastal erosion along the ice-rich coasts forming steep exposures (Forbes, 2011) or were technically constructed for research purposes, such as the CRREL (Cold Regions Research and Engineering Laboratory) Permafrost Tunnel in Barrow, or for mining, such as the Vault Creek Tunnel near Fairbanks, Alaska.

Coastal outcrops in Siberia were dominated by large late Pleistocene ice wedges reaching up to $20 \mathrm{~m}$ in depth and up to $6 \mathrm{~m}$ in width (Schirrmeister et al., 2011c). They formed syngenetically during periods of rapid sedimentation of Ice Complex deposits, also known as Yedoma (Schirrmeister et al., 2013). Holocene epigenetic and syngenetic ice wedges of
$1-6 \mathrm{~m}$ in depth and $<1.0-3.5 \mathrm{~m}$ in width were encountered in exposed thermokarst depressions of Lateglacial ${ }^{1}$ to Holocene origin and within the Holocene peaty cover deposits. Besides ice wedges, other types of massive ground ice were sampled, such as buried/basal glacier ice, buried lake ice and a fossil snow patch (Fig. 2). In some cases, massive ground ice occupied as much as $90 \mathrm{vol} \%$ of $40 \mathrm{~m}$ coastal exposures, erod-

\footnotetext{
${ }^{1}$ We refer to the Lateglacial as a stratigraphic and geochronological period at the transition between the Pleistocene and the Holocene. The Lateglacial spans the latest part of the Late Weichselian/Late Wisconsin glacial period. It includes the Bølling, the Older Dryas, the Allerød and the Younger Dryas, from ca. 14700 to 11600 years before present (cf. de Klerk, 2004).
} 
ing up to $10 \mathrm{~m} \mathrm{a}^{-1}$ (Lantuit et al., 2012). The focus of this paper is on massive ground ice; non-massive ice (in particular pore ice and intrasedimental ice such as ice lenses) was excluded from this first attempt to calculate DOC stocks in ground ice, because of the complex genetic processes associated with the interaction with enclosing sediment and the relatively small amount of ice relative to massive ice bodies. DOC in intrasedimental ice is, however, not considered to be insignificant.

\section{Material and methods}

\subsection{Laboratory analyses}

A total number of 101 ice samples from 29 ice bodies and 3 surface water samples from 3 thermokarst lakes were studied. Ice blocks were cut with a chain saw in the field and kept frozen until further processing with a band saw in a cold lab at $-15^{\circ} \mathrm{C}$ for removal of partially melted margins and cleaning of the edges. Samples $\geq 50 \mathrm{~mL}$ were thawed at $4{ }^{\circ} \mathrm{C}$ in pre-cleaned (purified water) glass beakers covered with pre-combusted aluminium foil $\left(550^{\circ} \mathrm{C}\right)$. Meltwater was filtered with gum-free syringes equipped with glass fiber filters (Whatman ${ }^{\text {TM }} \mathrm{GF} / \mathrm{F}$; pore size: $0.7 \mu \mathrm{m}$ ) and acidified with $20 \mu \mathrm{L} \mathrm{HCl}_{\text {suprapur }}(30 \%)$ to $\mathrm{pH}<2$ in order to prevent microbial conversion. DOC concentrations $\left(\mathrm{mg} \mathrm{L}^{-1}\right)$ were measured with a high-temperature $\left(680^{\circ} \mathrm{C}\right)$ combustion total organic carbon analyzer (Shimadzu TOC- $\mathrm{V}_{\mathrm{CPH}}$ ). Internal acidification is used to convert inorganic carbon into $\mathrm{CO}_{2}$, which is stripped out of solution. Non-purgeable organic carbon compounds are combusted and converted to $\mathrm{CO}_{2}$ and measured by a non-dispersive infrared detector (NDIR). The device-specific detection limit is $0.4 \mu \mathrm{g} \mathrm{L}^{-1}$. For each sample, one measurement with three to five repetitions was performed and results were averaged.

Further analyses for hydrochemical characterization included $\mathrm{pH}$, electrical conductivity, major anions and cations, and stable water isotopes $\left(\delta^{18} \mathrm{O}, \delta D\right)$. Stratigraphic investigations and stable water isotopes were used to differentiate between genetic ice types and to assess their approximate age (i.e., Holocene and late Pleistocene). Analyses of $\delta^{18} \mathrm{O}$ and $\delta D$ were carried out with a mass spectrometer (Finnigan MAT Delta-S) using the water-gas equilibration technique (for further information see Horita et al., 1989; Meyer et al., 2000). The isotopic composition is expressed in delta per mil notation $(\delta, \% o)$ relative to the Vienna Standard Mean Ocean Water standard. The reproducibility derived from long-term standard measurements is established with $1 \sigma$ better than $\pm 0.1 \%$ of $\delta^{18} \mathrm{O}$ and $\pm 0.8 \%$ for $\delta D$ (Meyer et al., 2000). Samples for ion analysis were passed through cellulose-acetate filters (Whatman ${ }^{\mathrm{TM}} \mathrm{CA}$; pore size $0.4 \mu \mathrm{m})$. Afterwards, samples for the cation analyses were acidified with $\mathrm{HNO}_{3}$ suprapur (65\%) to prevent microbial conversion processes and adsorptive accretion, whereas samples for anion analyses were kept cool. The cation content was analyzed by inductively coupled plasma-optical emission spectrometry (ICP-OES, Perkin-Elmer Optima 3000 XL), while the anion content was determined by ion chromatography (IC, Dionex DX-320). Hydrogen carbonate concentrations were measured by titration with $0.01 \mathrm{M} \mathrm{HCl}$ using an automatic titrator (Metrohm 794 Basic Titrino). Based on $\mathrm{HCO}_{3}^{-}$ concentrations we approximated the dissolved inorganic carbon (DIC) concentrations using the molecular weights.

\subsection{Statistical methods}

\subsubsection{Principal component analysis (PCA)}

Principal component analysis (PCA) was used to summarize the variation in a biplot by reducing dimensionality of the data while retaining most of the variation in the data set (Jolliffe, 2002). Ordinally scaled variables (i.e., chemical data set) were log-transformed, centered and standardized, except for $\mathrm{pH}, \delta^{18} \mathrm{O}, \delta D$, latitude and longitude not being log-transformed due the intersample invariance. Ice types (ice wedge, buried lake ice, basal glacier ice, snowpack ice, surface water) and relative age (Pleistocene, Holocene, recent) were coded with dummy variables and were superimposed as inactive supplementary variables on the ordination plot to enable rough assumptions about the relationship between chemical composition, ground-ice formation and age. The whole data set was reduced to 92 samples and 23 variables by removing those containing missing values. PCA was performed with a focus on interspecies correlation and was implemented using CANOCO 4.5 software for Windows (ter Braak and Šmilauer, 2002).

\subsubsection{Univariate tree model (UTM)}

A powerful tool to explore the relationship between a single continuous response variable (DOC concentration) and multiple explanatory variables is a regression tree (Zuur et al., 2007). Tree models perform well with nonlinearity and interaction between explanatory variables. UTMs are used to find interactions missed by other methods and also indicate the relative importance of different explanatory variables. Univariate tree modeling was performed using the computing environment $\mathrm{R}$ and Brodgar 2.6.5 software for Windows (ter Braak and Šmilauer, 2002; R Core Team, 2014).

\section{Results}

\subsection{DOC and DIC concentrations}

Table 2 provides an overview of mean DOC and DIC concentrations and range for each ground-ice type. We found strong variations of DOC concentrations within and across individual ground-ice types. The highest DOC concentrations were found in ice wedges with a mean of $9.6 \mathrm{mg} \mathrm{L}^{-1}$ 
Table 2. Summarized DOC and DIC concentrations of different massive ground-ice types. For individual sample values see Table S1.

\begin{tabular}{|c|c|c|c|c|c|c|c|c|c|}
\hline Ice type & $\begin{array}{r}\text { DOC } \\
\text { mean } \\
{\left[\mathrm{mgL}^{-1}\right]}\end{array}$ & $\begin{array}{r}\text { DOC } \\
\text { concentration } \\
\text { range }\left[\mathrm{mg} \mathrm{L}^{-1}\right]\end{array}$ & $\begin{array}{r}\text { No. } \\
\text { of ice } \\
\text { bodies }\end{array}$ & $\begin{array}{r}\text { No. } \\
\text { of } \\
\text { samples }\end{array}$ & $\begin{array}{r}\text { DIC } \\
\text { mean } \\
{\left[\mathrm{mg} \mathrm{L}^{-1}\right]}\end{array}$ & $\begin{array}{r}\text { DIC } \\
\text { concentration } \\
\text { range }\left[\mathrm{mg} \mathrm{L}^{-1}\right]\end{array}$ & $\begin{array}{r}\text { No. } \\
\text { of ice } \\
\text { bodies }\end{array}$ & $\begin{array}{r}\text { No. } \\
\text { of } \\
\text { samples }\end{array}$ & $\begin{array}{l}\text { Stratigraphic } \\
\text { affiliation }\end{array}$ \\
\hline $\begin{array}{l}\text { Ice wedge } \\
\text { ice }\end{array}$ & 9.6 & $1.6-28.6$ & 22 & 72 & 4.7 & $0.3-19.8$ & 21 & 66 & $\begin{array}{l}\text { Holocene, late } \\
\text { Pleistocene }\end{array}$ \\
\hline $\begin{array}{l}\text { Buried/basal glacier } \\
\text { ice }\end{array}$ & 1.8 & $0.7-3.8$ & 5 & 22 & 9.3 & $0.1-25.4$ & 4 & 19 & Late Pleistocene \\
\hline $\begin{array}{l}\text { Buried lake } \\
\text { ice }\end{array}$ & 2.0 & $0.3-5.2$ & 1 & 6 & 8.8 & $0.3-22.9$ & 1 & 6 & Late Pleistocene \\
\hline Snowpack ice & 3.0 & n.a. & 1 & 1 & n.a. & n.a. & & & Holocene \\
\hline $\begin{array}{l}\text { Modern } \\
\text { surface water* }\end{array}$ & 5.6 & $5.5-5.7$ & 3 & 3 & 22.6 & $5.0-40.2$ & 3 & 3 & Recent \\
\hline
\end{tabular}

* Three modern surface water samples are from three different water bodies representing thermokarst ponds along the Yukon coast.

and a maximum of $28.6 \mathrm{mg} \mathrm{L}^{-1}$. Late Pleistocene ice wedges were characterized by higher mean DOC concentrations than Holocene ones, with 11.1 and $7.3 \mathrm{mg} \mathrm{L}^{-1}$, respectively. Other ice types had average DOC concentrations between 1.8 and $3.0 \mathrm{mg} \mathrm{L}^{-1}$, and their range was narrower than in ice wedges (Table 2, Fig. 3). Modern surface water gave DOC values between 5.5 and $5.8 \mathrm{mg} \mathrm{L}^{-1}$.

The highest DIC concentrations were found in modern surface water with on average $22.6 \mathrm{mg} \mathrm{L}^{-1}$ and a maximum of $40.2 \mathrm{mg} \mathrm{L}^{-1}$ (Table 2, Fig. 3). DIC concentrations were lower in ground ice but varied strongly across ice types. With $8.5 \mathrm{mg} \mathrm{L}^{-1}$, late Pleistocene ice wedges were characterized by almost 4-times-higher mean DIC concentrations than Holocene ones (2.2 $\mathrm{mg} \mathrm{L}^{-1}$; Fig. 3). Buried glacier ice and lake ice had similar mean DIC concentrations (around $9 \mathrm{mg} \mathrm{L}^{-1}$ ) but showed large ranges: from values around 0 up to $25 \mathrm{mg} \mathrm{L}^{-1}$. Basal glacier ice, buried lake ice and snowpack ice show mean DOC concentrations between 1.8 and $3.0 \mathrm{mg} \mathrm{L}^{-1}$. For individual sample values see Supplement Table S1.

\subsection{Correlation matrix}

With the help of a correlation matrix (Corrgram Package v1.6 in $\mathrm{R}$ version 3.1.2, $\mathrm{R}$ Core Team, 2014), environmental processes and chemical relationships can be visualized that may help to explain the sequestration of DOC into ground ice. Pearson's correlation coefficients were calculated and plotted in a correlation matrix in order to assess the degree of association between DOC, chemical properties, stable water isotopes and spatial variables (Fig. 4). A strong positive correlation suggests a mutual driving mechanism, whereas negative values imply an inverse association. Most importantly, DOC is positively related to the relative proportion of $\mathrm{Mg}^{2+}$ in the cation spectrum $(R=0.65)$. Further positive relations between DOC and other parameters, although less pronounced, involve $\mathrm{K}^{+}(R=0.36), \mathrm{HCO}_{3}^{-}(R=0.36)$ and latitude $(R=0.38)$. The only significantly negative relationship with regard to DOC exists together with $\mathrm{Na}^{+}(R=-0.44)$
(Fig. 4). Climate-driven parameters such as $\delta^{18} \mathrm{O}, \delta D$ and $D$ excess do not explain DOC concentrations.

\subsection{Principal components}

The first two axes of the PCA explain $43.9 \%$ of the variation in the data (Fig. 5). $\mathrm{Cl}^{-}$and $\mathrm{Na}^{+}$ions are positively correlated with the first axis in descending order of correlation, whereas $\mathrm{Ca}^{2+}, \mathrm{Mg}^{2+}$ and $\mathrm{HCO}_{3}^{-}$ions and $\mathrm{pH}$ are negatively correlated. Parameters positively correlated with PCA axis 2 include information on the ice origin of Pleistocene and basal glacier ice. In contrast, $\delta D, \delta^{18} \mathrm{O}$, DOC concentration and information on the ice origin such as ice wedges and Holocene ground ice are negatively correlated with PCA axis 2. Variations in $\mathrm{SO}_{4}^{2-}$ and $\mathrm{NO}_{3}^{-}$concentration as well as information on latitude and longitude are not correlated with the first two PCA axes. The separation of ice samples in the PCA ordination plot leads to three distinct groups: (1) Holocene ice wedges and recent surface water samples are entirely negatively related to the second axis, whereas (2) Pleistocene ice wedges are entirely negatively related to the first axis. (3) Pleistocene basal glacier ice and buried lake ice are positively related to the second axis. This separation might be related to the different processes of ice formation and climate variation.

$\mathrm{Na}^{+}$- and $\mathrm{Cl}^{-}$-dominated samples represent Holocene ice wedges from coastal cliffs in east Siberia (Muostakh Island and Oyogos Yar). The majority of ice wedges with a terrestrial ion composition $\left(\mathrm{Mg}^{2+}, \mathrm{Ca}^{2+}, \mathrm{HCO}_{3}^{-}\right)$are of late Pleistocene age in areas such as Mamontov Klyk, Bol'shoy Lyakhovsky Island, Yukon coast and the Fairbanks area. The first axis probably separates samples with a strong marine impact at its upper end from those with more of a continental background. The second axis might represent climate conditions of formation. The majority of Pleistocene ice samples with a depleted stable water isotope composition show positive sample scores, whereas Holocene ground ice, being enriched in heavy stable water isotopes, mostly shows negative sample scores and therefore plots in the lower part of the PCA (Fig. 5). 



Figure 3. Boxplots of (a) DOC and (b) DIC concentrations in different massive ground-ice types. Plots show minimum, maximum and median values (25th percentile and 75th percentile as edge of boxes) and the number of samples in each category. IW: ice wedges (all), IW-P: Pleistocene ice wedges; IW-H: Holocene ice wedges; BGI: buried glacier ice; BLI: buried lake ice; SPI: snowpack ice; SW: surface water. For individual sample values see Table S1.

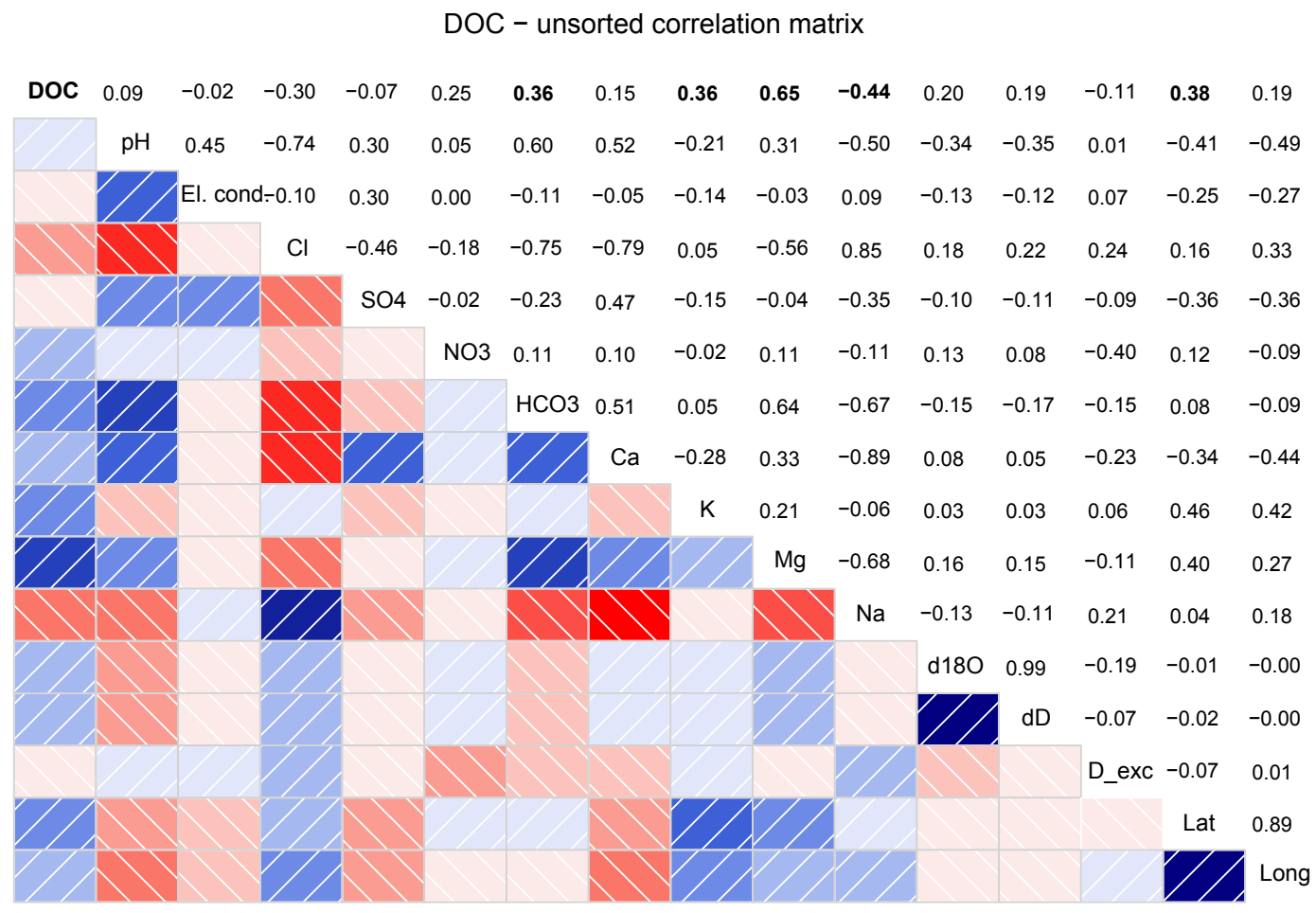

Figure 4. Correlation matrix. Correlations mentioned in the text are printed in bold. Strong positive correlations of paired variables are indicated by dark bluish colors, while strong anti-correlations are depicted in red. Hatching from the upper right to the lower left depicts positive correlations, whereas negative correlations are reversely hatched for better perceptibility in a black-and-white print. (For interpretation of the references to color in this figure legend, the reader is referred to the web version of this article.)

\subsection{Univariate tree model}

The UTM (Fig. 6a) shows that differences in DOC concentrations can be explained according to inorganic geochemical properties. The first two nodes split on $\mathrm{Mg}^{2+}$ with a threshold value of $16 \%$ of the cation spectrum. The next nodes split ac- cording to thresholds in $\mathrm{K}^{+}$of 2.30 and $2.65 \%$, respectively (Fig. 6a). Threshold percentages presented here are based on the cation spectrum only. This means that all measured cations sum up to $100 \%$. This is statistically more robust than using individual sample concentrations which can have different magnitudes. We end up with four statistically signif- 


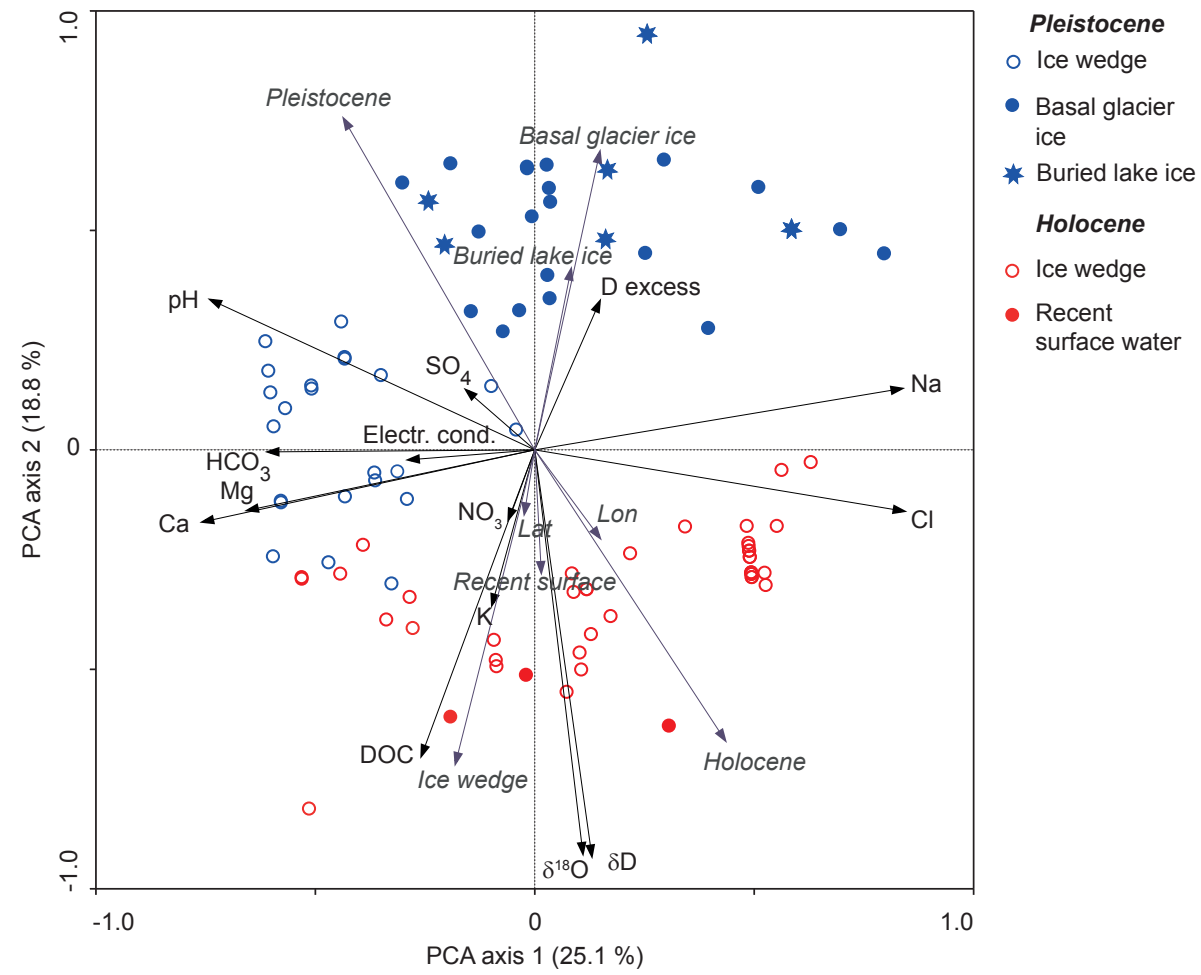

Figure 5. PCA biplot for ground-ice data. Inactive supplementary parameters (i.e., ice wedge, buried lake ice, basal glacier ice, snowpack ice, surface water, Pleistocene, Holocene, recent) are shown in grey italic. For individual sample values see Table S1.

icant groups (i.e., nodes) with different mean DOC concentrations $\left(\mathrm{mg} \mathrm{L}^{-1}\right)$ of each group, also showing the number of observations in each group $(n)$. With the UTM information - that inorganic geochemistry explains the variability in DOC concentration - we can make assumptions about relations between carbon sequestration in different water types. DOC concentration is not independent from inorganic geochemical composition. Cross validation (Fig. 6b) confirms the statistical significance of the model result.

\section{Discussion}

\subsection{DOC stocks in ground ice and relevance to carbon cycling}

While the riverine DOC export to the Arctic Ocean has been estimated as 33-34 $\mathrm{Tg} \mathrm{a}^{-1}$ (McGuire et al. 2009; Holmes et al., 2012), comparable numbers for the DOC input by coastal erosion and thermal permafrost degradation (also known as thermokarst) are not available yet. This knowledge gap includes the DOC contribution derived from melting ground ice from ice-rich permafrost. Table 2 provides an overview of DOC contents in different massive ground-ice types from the North American and Siberian Arctic. Because of their wide spatial distribution in Arctic lowlands and the measured DOC concentrations, we conclude that, of massive ground- ice types, ice wedges hold the greatest potential for DOC storage with a maximum of $28.6 \mathrm{mg} \mathrm{L}^{-1}$. This is in good agreement with DOC measurements in a so-far limited number of ice wedges by Douglas et al. (2011) in Alaska and Vonk et al. (2013b) in east Siberia, who showed DOC concentrations of $18.4-68.5 \mathrm{mg} \mathrm{L}^{-1}(n=5)$ and $8.8-15 \mathrm{mg} \mathrm{L}^{-1}$ $(n=3)$, respectively.

Ulrich et al. (2014) have calculated maximum wedgeice volumes (WIVs), which range from 31.4 to $63.2 \mathrm{vol} \%$ for late Pleistocene Yedoma deposits and from 6.6 to $13.2 \mathrm{vol} \%$ for Holocene thermokarst deposits in east Siberia and Alaska. Strauss et al. (2013) have shown similar averages for WIVs of $48 \mathrm{vol} \%$ in late Pleistocene Yedoma and $7.0 \mathrm{vol} \%$ for Holocene thermokarst deposits. Together with average DOC concentrations of $11.1 \mathrm{mg} \mathrm{L}^{-1}(\max 28.6)$ this would lead to $5.3 \mathrm{~g}$ DOC $~ m^{-3}(\max 18.1)$ for late Pleistocene ice wedges in the upper late Pleistocene permafrost column (Table 3) and a DOC pool of 43.0 Tg DOC based on $416000 \mathrm{~km}^{2}$ of undisturbed Yedoma in Beringia and a mean thickness of $19.4 \mathrm{~m}$ (Strauss et al., 2013). DOC stocks in ice wedges in Holocene thermokarst deposits are much lower with on average $0.51 \mathrm{~g} \mathrm{~m}^{-3}$ and a maximum of $2.6 \mathrm{~g} \mathrm{~m}^{-3}$ due to much lower WIVs (cf. Ulrich et al., 2014) and slightly lower DOC concentrations (Table 3 ). With on average $2.2 \mathrm{Tg}$ the Holocene ice wedge DOC pool is much lower than the late Pleistocene pool, mainly because of lower WIVs and an average thickness of $5.5 \mathrm{~m}$ for thermokarst de- 
Table 3. DOC stocks and pools in late Pleistocene and Holocene permafrost containing ice wedges (IW) based on calculated wedge-ice volumes (WIVs) in Yedoma and thermokarst basin deposits. All other ground-ice types, especially non-massive intrasedimental ice, are not included.

\begin{tabular}{|c|c|c|c|c|c|c|c|c|}
\hline & $\begin{array}{r}\text { DOC } \\
\text { concentra- } \\
\text { tion in } \\
\text { Pleistocene IW } \\
\mathrm{mg} \mathrm{L}^{-1}\end{array}$ & $\begin{array}{r}\text { DOC } \\
\text { concentra- } \\
\text { tion in } \\
\text { Holocene IW } \\
\mathrm{mg} \mathrm{L}^{-1}\end{array}$ & $\begin{array}{r}\text { WIV in } \\
\text { Pleistocene } \\
\text { Yedoma } \\
\text { deposits } \\
\text { vol\% }\end{array}$ & $\begin{array}{r}\text { WIV in } \\
\text { Holocene } \\
\text { thermokarst } \\
\text { deposits } \\
\text { vol\% }\end{array}$ & $\begin{array}{r}\text { DOC } \\
\text { stocks in } \\
\text { Pleistocene } \\
\text { permafrost } \\
\text { g m }^{-3}\end{array}$ & $\begin{array}{r}\text { DOC } \\
\text { stocks in } \\
\text { Holocene } \\
\text { permafrost } \\
\text { g m }^{-3}\end{array}$ & $\begin{array}{r}\text { DOC } \\
\text { pools in } \\
\text { Pleistocene } \\
\text { permafrost }{ }^{\mathrm{c}, \mathrm{d}} \\
\mathrm{Tg}\end{array}$ & $\begin{array}{r}\text { DOC } \\
\text { pools in } \\
\text { Holocene } \\
\text { permafrost }{ }^{\mathrm{c}, \mathrm{d}} \\
\mathrm{Tg}\end{array}$ \\
\hline Min & 2.4 & 1.6 & $16.7^{\mathrm{a}}$ & $1.0^{\mathrm{a}}$ & 0.4 & 0.02 & 3.2 & 0.07 \\
\hline Mean & 11.1 & 7.3 & $48.0^{\mathrm{b}}$ & $7.0^{\mathrm{b}}$ & 5.3 & 0.51 & 43.0 & 2.2 \\
\hline Max & 28.6 & 19.5 & $63.2^{\mathrm{a}}$ & $13.2^{\mathrm{a}}$ & 18.1 & 2.6 & 145.9 & 11.0 \\
\hline
\end{tabular}

${ }^{\mathrm{a}}$ WIV data by Ulrich et al. (2014). ${ }^{\mathrm{b}}$ Mean WIV data by Strauss et al. (2013). ${ }^{\mathrm{c}}$ This includes ice wedges only. ${ }^{\mathrm{d}}$ According to Strauss et al. (2013) undisturbed Pleistocene Yedoma covers $416000 \mathrm{~km}^{2}$ with a mean thickness of $19.4 \mathrm{~m}$, whereas Holocene thermokarst deposits cover $775000 \mathrm{~km}^{2}$ with a mean thickness of $5.5 \mathrm{~m}$.

a) Tree model

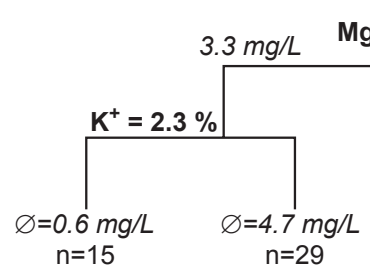

b)

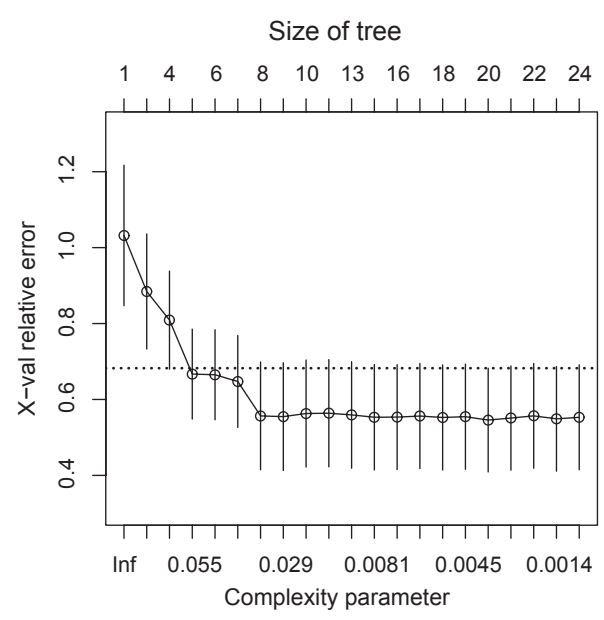

Figure 6. Univariate tree model (UTM) explains variability pattern in DOC concentration. (a) The tree model focuses on DOC concentration as response variable. The UTM uses 92 observations and a set of 22 explanatory variables. $\mathrm{Mg}^{2+}$ and $\mathrm{K}^{+}$ions are most important to explain differences in DOC concentrations. Mean DOC concentrations of each group in $\mathrm{mg} \mathrm{L}^{-1}$. Number of observations in each group $(n)$. (b) Cross validation determines the statistically significant size of the tree model. The dotted line is obtained by the mean value of the errors ( $x$ error) of the cross validations plus the standard deviation of the cross validations upon convergence. For individual sample values see Table S1. posits, and despite their greater extent $\left(775000 \mathrm{~km}^{2}\right)$ than undegraded Yedoma deposits (Strauss et al., 2013). Even stronger differences are characteristic for DIC pools in late Pleistocene ice wedges $(32.9 \mathrm{Tg}$ ) compared to Holocene ice wedges $(0.66 \mathrm{Tg})$ in the same areas. Based on the abovementioned spatial coverage of Yedoma and thermokarst deposits, including sediment thickness and WIVs, we conclude that in the study area ice wedges represent a significant DOC $(45.2 \mathrm{Tg})$ and DIC (33.6 Tg) pool in permafrost areas and a freshwater reservoir of $4200 \mathrm{~km}^{2}$ (see Table 3).

However, all types of non-massive intrasedimental ice, raising the total ground-ice volume to $\sim 80 \%$ (Schirrmeister et al., 2011b; Strauss et al., 2013), are still excluded. DOC concentrations in non-massive intrasedimental ice from $\mathrm{Mu}-$ ostakh Island (Siberia) and the Yukon coast (Canada) have been found to be much higher (Fritz, unpublished data). Higher DOC concentrations in intrasedimental ice than in massive ice are certainly due to the long-term contact of soil moisture with soil organic matter prior to freezing. We therefore suggest that distinguishing DOC and POC also in analyses of non-massive ground-ice types (pore ice and intrasedimental ice) would lead to a significant rise in the proportion between DOC and POC in permafrost. However, a differentiation between particulate and dissolved OC in permafrost has not been done yet, although the technical means via rhizon soil moisture sampling is already available on a costand time-efficient basis. Nevertheless, we are aware of the fact that DOC makes up a limited proportion of the whole permafrost carbon stocks. A cautious estimation of the ratio of DOC and POC is on the order of $\sim 1 / 2000$ if we consider about $2 \mathrm{wt} \%$ total organic carbon (TOC) in sediments (e.g., Schirrmeister et a., 2011b, c; Strauss et al., 2013) and about $10 \mathrm{mg} \mathrm{L}^{-1}$ DOC in massive ground ice. This ratio will become much smaller if POC and DOC in the whole permafrost column were differentiated, because TOC comprises both POC and DOC. 


\subsection{Carbon sequestration and origin in relation to inorganic geochemistry}

The origin and sequestration process into ground ice seems to play an important role in the magnitude and bioavailability of DOC. Sequestration of OC into ground ice is a complex process that is dependent on water source, freezing process, organic matter origin and inorganic geochemical signature of the ambient water to form ground ice.

Figures 4 and $6 a$ show that the electrical conductivity (i.e., total ion content) of ground ice is unrelated to DOC but that the ion composition and therefore the ion source seem to be relevant. $\mathrm{Mg}^{2+}$ and $\mathrm{K}^{+}$are the most significant parameters for explaining variations in DOC concentrations (Fig. 6a). Higher $\mathrm{Mg}^{2+}$ and $\mathrm{K}^{+}$fractions of the cations spectrum are positively related to higher DOC concentrations (Fig. 4). We recognize that in the node (group) with the highest average DOC concentrations $\left(\varnothing=11.9 \mathrm{mg} \mathrm{L}^{-1}, n=40\right)$ we find most of the Pleistocene ice wedges and to a lesser extent Holocene ice wedges (Fig. 6a). All study areas are represented here. Both $\mathrm{Mg}^{2+}$ and $\mathrm{K}^{+}$have typically high shares in terrestrial water types because $\mathrm{Mg}$ and $\mathrm{K}$ are major elements in clay minerals and feldspars. In combination with terrestrial $\mathrm{HCO}_{3}^{-}$and $\mathrm{Ca}^{2+}$ the mobility of $\mathrm{Mg}^{2+}$ is high in $\mathrm{Mg} / \mathrm{Ca}\left(\mathrm{HCO}_{3}\right)_{2}$ solutions (Gransee and Führs, 2013).

Ice wedges are fed by meltwater from atmospheric sources that have been in contact with vegetation and sediments of the tundra surface before meltwater infiltrated the frost cracks in spring. By contrast, glacier ice, snowbank ice and lake ice are primarily fed by atmospheric waters having less interaction with carbon and ion sources. Yet, the yellowish brown to gray late Pleistocene and the milky-white Holocene ice wedges have incorporated sediments and organic matter that originate from surface soils and vegetation debris that was carried along with the meltwater into the frost crack (e.g., Opel et al., 2011). Spring snow meltwater interacts with the soil material leaching out carbon as it trickles downward toward the ice wedges. Also, since wedges may take thousands of years to form and the location of their upper surface changes with time, there are numerous spatial and temporal ways that deeper soil pore waters can get incorporated into the wedge ice. Leaching of DOC from relatively young surface organic matter takes place (Guo et al., 2007; Lachniet et al., 2012) as well as dissolution of ions from sediment particles. Snowmelt feeding ice wedges strongly attracts leachable components because of its initial purity. This might be the reason why especially ice wedges contain relatively high amounts of bioavailable DOC with lowmolecular-weight compounds that may be old but remained fresh over millennia (Vonk et al., 2013b).

Principal component analysis clusters ice wedges into two main groups along the first axis based on $\mathrm{Na}^{+}$and $\mathrm{Cl}^{-}$ dominating Holocene ice wedges in modern coastal settings and $\mathrm{Mg}^{2+}, \mathrm{Ca}^{2+}$ and $\mathrm{HCO}_{3}^{-}$for Pleistocene ice wedges and Holocene ones being far from coasts (Fig. 5). This pat- tern depicts the competing influence of maritime and terrestrial/continental conditions. A similar differentiation of ice wedges (and all ground-ice types) is done along the second PCA axis (Fig. 5). Differences in stable water isotopes indicate the predominant climate variations between the late Pleistocene and the Holocene which are also reflected in the landscape (i.e., distance to sea; maritime vs. continental). Distance from the coastline is crucial for the incorporation of marine-derived ions through aerosols such as $\mathrm{NaCl}$ via sea spray. While the Fairbanks area is the only site far inland, all other study sites except for Samoylov Island in the central Lena River delta are coastal areas today. However, during the late Pleistocene global sea level was lower and large parts of the shallow circum-Arctic shelves were subaerially exposed. Present-day coastal sites were located up to hundreds of kilometers inland. Marine ion transport via sea spray is not expected to have played a role on inland sites but indeed since the rapid marine transgression during the Holocene that changed far-inland sites into coastal ones. Input of sea spray is only relevant during the open-water season so that a prolonged ice cover during the late Pleistocene (Nørgaard-Pedersen et al., 2003; Bradley and England, 2008) should have further reduced the influx of sea salt. Additionally, sustained dry conditions (Carter, 1981; Alfimov and Berman, 2001; Murton, 2009) probably increased eolian input of terrestrial material into ice wedges, which is then directly mirrored in the hydrochemical signature.

So far we have shown that coastal/maritime and terrestrial environmental conditions can be differentiated based on inorganic hydrochemistry and that terrestrial surface OC sources feed the DOC signal in ice wedges. DOC sequestration into ground ice is also dependent on active-layer properties, vegetation cover, vegetation communities and deposition rates. Long-term stable surfaces and relatively constant active-layer depths will lead to substantially leached soil layers in terms of DOC (Guo and Macdonld, 2006) and inorganic solutes (Kokelj et al., 2002). Based on $\Delta{ }^{14} \mathrm{C}$ values and $\delta^{13} \mathrm{C}$ ratios on DOC from soil-leaching experiments and natural river water samples, Guo et al. (2007) have shown that intensive leaching of DOC from young and fresh plant litter and upper soil horizons occurs during the snowmelt period. Later in the season, DOC yields decreased in rivers draining permafrost areas, indicating that deepening of the active layer and leaching of deeper seasonally frozen soil horizons were accompanied by much lower concentrations of DOC due to the refractory and insoluble character of the remaining organic matter compounds. In addition, dissolved organic matter compounds in runoff into lakes and rivers can become rapidly degraded by microbial communities and photochemical reactions (Striegl et al., 2005; Olefeldt and Roulet, 2012; Cory et al., 2014). One destination of the fresh, young and therefore most bioavailable DOC components will be ice wedges (Vonk et al., 2013b), where the chemical character is preserved because of immediate freezing. This highlights the 
importance of ground ice, and especially of ice wedges, as a vital source of bioavailable DOC.

\subsection{DOC mobility and quality upon permafrost degradation}

The absolute numbers of DOC in permafrost might still be small compared to the POC. However, POC from both peat and mineral soil has a relatively slow decomposition rate after thaw compared to DOC (Schuur et al., 2008). Organic matter from melting ground ice was shown to be highly bioavailable and can even enhance organic matter degradation of the host material by increased enzyme activity in ice wedge meltwater (Vonk et al., 2013b). Bioavailability experiments with Yedoma DOC from thaw streams fed by ice wedge meltwater in NE Siberia illustrated the rapid decomposability of Yedoma OC, with OC losses of up to $33 \%$ in 14 days (Vonk et al., 2013a). Incubations with increasing amounts of ice wedge water in the Yedoma-water suspension enhanced DOC loss over time. Vonk et al. (2013b) concluded that ice wedges contain a DOM pool of reduced aromaticity and can therefore be regarded as an old but readily available carbon source with a high content of low-molecularweight compounds. Additionally, a co-metabolizing effect through high potential enzyme activity in ice wedges upon thaw leads to enhanced degradation rates of organic matter of the host material. When studying organic matter cycling in permafrost areas, we have to abandon the paradigm, which holds true for temperate regions and Arctic oceanography, that old OC is refractory and that only young OC is fresh, bioavailable and therefore relevant for foods webs and greenhouse gas considerations.

We suggest that reduced organic matter degradation during cold periods is the main reason why late Pleistocene syngenetic ice wedges have incorporated more DOC on average than Holocene ice wedges. Incorporation of soluble organic matter into ground ice might have been more effective than today for various reasons. Ice Complex deposits in the coastal lowlands formed during the late Pleistocene cold period, when high accumulation rates of fine-grained sediments and organic matter were accompanied by rapidly aggrading permafrost (Hubberten et al., 2004). This means that organic matter is less decomposed because it was rapidly incorporated into perennially frozen ground and into the surrounding syngenetic ice wedges as the permafrost table rose together with the rising surface during deposition (Schirrmeister et al., 2011b). Also, colder annual air temperatures led to reduced decomposition rates of organic matter which originated from vegetation communities dominated by easily decomposable forbs (Willerslev et al., 2014) in contrast to resistant sedge-moss-shrub tundra vegetation since postglacial times (Andreev et al., 2011). Additionally, low precipitation and reduced runoff presumably retained more DOC in the landscape, ready to be transported into frost cracks.
Guo et al. (2007) concluded that most of the DOC in Arctic rivers is derived from young and fresh plant litter and upper soil horizons. Leaching of deeper seasonally frozen soil horizons is accompanied by much lower DOC concentrations due to the refractory and insoluble character of the remaining organic matter compounds (Guo et al., 2007). DOC impoverishment in the active layer is logical as it is leached each season over a long time under modern climate conditions, where permafrost aggradation is much slower than during cold stages - if it happens at all. The quantity and quality of DOC pools in deeper permafrost is probably much higher because of - so far - suppressed remobilization. Dou et al. (2008) studied the production of DOC as water-extractable organic carbon yields from organic-rich soil horizons in the active layer and permafrost from a coastal bluff near Barrow (Alaska) facing the Beaufort Sea. Besides high DOC yields in the uppermost horizon $(0-5 \mathrm{~cm}$ below surface) the second-highest DOC yields derived from permafrost although the sampled horizon showed lower soil OC contents than others (Dou et al., 2008). Interestingly, higher fractions of low-molecular-weight DOC, which is regarded to be more bioavailable, were generally found at greater depths. This supports the view that permafrost deposits hold a great potential for mobilizing large quantities of highly bioavailable organic matter upon degradation. Coastal erosion and thermokarst often expose old and deep permafrost strata. Contained organic matter is directly exposed to the atmosphere and transferred into coastal and freshwater ecosystems without degradation because of short travel and residence times. Therefore, Arctic coastal zones are supposed to receive high loads of bioavailable dissolved and particulate organic matter. Dou et al. (2008) used pure water (presumably MilliQ) and natural sea water as a solvent for studying the production of DOC. It turned out that seawater extraction significantly reduced DOC yields which were attributed mainly to reduced solubility of humic substances due to the presence of polyvalent cations such as $\mathrm{Ca}^{2+}$ and $\mathrm{Mg}^{2+}$ in seawater (Aiken and Malcolm, 1987). On the one hand Dou et al. (2008) invoked that a laboratory setup using pure water and dried/rewetted soil samples would lead to an overestimation of DOC input to the Arctic Ocean during coastal erosion. On the other hand and based on the large ground-ice volumes in coastal cliffs (Lantuit et al., 2012), we suggest that ice wedge meltwater with a low ion content is probably able to leach greater amounts of DOC from permafrost upon thaw than other natural surface water.

An open question remains as to how much DOC can be found in intrasedimental ice and how much DOC is produced upon degradation of old permafrost (e.g., late Pleistocene Yedoma type), for example as a result of coastal erosion. To answer this question, it is crucial to follow the fate of permafrost organic matter upon remobilization. Additionally, robust estimations of carbon release are crucial for predicting the strength and timing of carbon-cycle feedback effects, 
and thus how important permafrost thaw will be for climate change this century and beyond.

\section{Conclusions and outlook}

Ground ice in ice-rich permafrost deposits contains DOC, DIC and other nutrients which are relevant to the global carbon cycle, Arctic freshwater habitats and marine food webs upon release.

The following conclusions can be drawn from this study:

- Ice wedges represent a significant DOC (45.2 Tg) and DIC (33.6 Tg) pool in the studied permafrost areas and a considerable freshwater reservoir of $4200 \mathrm{~km}^{2}$.

- Syngenetic late Pleistocene ice wedges have the greatest potential to host a large pool of presumably bioavailable DOC because of (i) highest measured average DOC concentrations in combination with (ii) their wide spatial (lateral, vertical) distribution in ice-rich permafrost areas and (iii) the sequestration of fresh and easily leachable OC compounds.

- Increased incorporation of DOC into ground ice is linked to relatively high proportions of terrestrial cations, especially $\mathrm{Mg}^{2+}$ and $\mathrm{K}^{+}$. This indicates that leaching of terrestrial organic matter is the most relevant process of DOC sequestration into ground ice.

Based on our results about the stocks and chemical behavior of DOC in massive ground-ice bodies we propose that further studies shall strive to

- quantify DOC fluxes in the Arctic from thawing permafrost, melting ground ice and coastal erosion;

- differentiate between DOC and POC in permafrost including non-massive intrasedimental ice;

- quantify DOC production from permafrost in different stratigraphic settings and with different natural solvents to answer the question of what fraction of soil OC will be leached as DOC;

- assess the age and lability of DOC versus POC in permafrost and the potential impact on coastal food webs and freshwater ecosystems.

\section{The Supplement related to this article is available online at doi:10.5194/tc-9-737-2015-supplement.}

Acknowledgements. We thank the Yukon territorial government; the Herschel Island Qiqiktaruk Territorial Park; the Parks Canada office; and the Aurora Research Institute - Aurora College (ARI) in Inuvik, NWT, for administrative and logistical support. This study was partly funded by the International Bureau of the German Federal Ministry of Education and Research (grant no. CAN 09/001, 01DM12002 to H. Lantuit), the Helmholtz Association (grant no. VH-NG-801 to H. Lantuit), the German Research Foundation (grant no. OP217/2-1 to T. Opel) and a fellowship to M. Fritz by the German Federal Environmental Foundation (DBU). Analytical work at AWI received great help from Ute Kuschel. Sebastian Wetterich, Dave Fox and Stefanie Weege assisted in the field. We acknowledge two anonymous reviewers and the editor Stephan Gruber for their helpful comments and suggestions.

Edited by: S. Gruber

\section{References}

Aiken, G. R. and Malcolm, R. L.: Molecular weight of aquatic fulvic acids by vapor pressure osmometry, Geochim. Cosmochim. Ac., 51, 2177-2184, 1987.

Alfimov, A. V. and Berman, D. I.: Beringian climate during the Late Pleistocene and Holocene, Quaternary Sci. Rev., 20, 127-134, 2001.

Andreev, A. A., Tarasov, P., Schwamborn, G., Ilyashuk, B., Ilyashuk, E., Bobrov, A., Klimanov, V., Rachold, V., and Hubberten, H.-W.: Holocene paleoenvironmental records from Nikolay Lake, Lena River Delta, Arctic Russia, Palaeogeogr. Palaeoclimatol. Palaeoecol., 209, 197-217, 2004.

Andreev, A. A., Grosse, G., Schirrmeister, L., Kuznetsova, T. V., Kuzmina, S. A., Bobrov, A. A., Tarasov, P. E., Novenko, E. Y., Meyer, H., Derevyagin, A. Y., Kienast, F., Bryantseva, A., and Kunitsky, V. V.: Weichselian and Holocene palaeoenvironmental history of the Bol'shoy Lyakhovsky Island, New Siberian Archipelago, Arctic Siberia, Boreas, 38, 72-110, 2009.

Andreev, A. A., Schirrmeister, L., Tarasov, P. E., Ganopolski, A., Brovkin, V., Siegert, C., Wetterich, S., and Hubberten, H.-W.: Vegetation and climate history in the Laptev Sea region (Arctic Siberia) during Late Quaternary inferred from pollen records, Quaternary Sci. Rev., 30, 2182-2199, 2011.

Battin, T. J., Kaplan, L. A., Findlay, S., Hopkinson, C. S., Marti, E., Packman, A. I., Newbold, J. D., and Sabater, F.: Biophysical controls on organic carbon fluxes in fluvial networks, Nature Geosci., 1, 95-100, 2008.

Benner, R., Benitez-Nelson, B., Kaiser, K., and Amon, R. M. W.: Export of young terrigenous dissolved organic carbon from rivers to the Arctic Ocean, Geophys. Res. Lett., 31, L05305, doi:10.1029/2003g1019251, 2004.

Boereboom, T., Samyn, D., Meyer, H., and Tison, J. L.: Stable isotope and gas properties of two climatically contrasting (Pleistocene and Holocene) ice wedges from Cape Mamontov Klyk, Laptev Sea, northern Siberia, The Cryosphere, 7, 31-46, doi:10.5194/tc-7-31-2013, 2013.

Bradley, R. S. and England, J. H.: The Younger Dryas and the Sea of Ancient Ice, Quaternary Res., 70, 1-10, 2008.

Brown, J., Ferrians, O. J., Jr., Heginbottom, J. A., and Melnikov, E. S. (Eds.): Circum-Arctic map of permafrost and ground-ice conditions. Washington, DC: U.S. Geological Survey in Cooperation with the Circum-Pacific Council for Energy and Mineral Re- 
sources, Circum-Pacific Map Series CP-45, scale 1 : 10000000 , 1 sheet, 1997.

Carter, L. D.: A Pleistocene sand sea on the Alaskan Arctic Coastal Plain, Science, 211, 381-383, 1981.

Cooper, L. W., Benner, R., McClelland, J. W., Peterson, B. J., Holmes, R. M., Raymond, P. A., Hansell, D. A., Grebmeier, J. M., and Codispoti, L. A.: Linkages among runoff, dissolved organic carbon, and the stable oxygen isotope composition of seawater and other water mass indicators in the Arctic Ocean, J. Geophys. Res., 110, G02013, doi:10.1029/2005jg000031, 2005.

Cory, R. M., Ward, C. P., Crump, B. C., and Kling, G. W.: Sunlight controls water column processing of carbon in arctic fresh waters, Science, 345, 925-928, 2014.

Czudek, T. and Demek, J.: Thermokarst in Siberia and its influence on the development of lowland relief, Quaternary Res., 1, 103120, 1970.

de Klerk, P.: Confusing concepts in Lateglacial stratigraphy and geochronology: origin, consequences, conclusions (with special emphasis on the type locality B $\varnothing$ llings $\emptyset$ ), Rev. Palaeobot. Palynol., 129, 265-298, 2004.

Dittmar, T. and Kattner, G.: The biogeochemistry of the river and shelf ecosystem of the Arctic Ocean: a review, Mar. Chem., 83, 103-120, 2003.

Dou, F., Ping, C.-L., Guo, L., and Jorgenson, T.: Estimating the impact of seawater on the production of soil water-extractable organic carbon during coastal erosion, J. Environ. Qual., 37, 23682374, 2008

Douglas, T. A., Fortier, D., Shur, Y. L., Kanevskiy, M. Z., Guo, L., Cai, Y., and Bray, M. T.: Biogeochemical and geocryological characteristics of wedge and thermokarst-cave ice in the CRREL permafrost tunnel, Alaska, Permafr. Periglac. Proc., 22, 120-128, 2011.

Finlay, J., Neff, J., Zimov, S., Davydova, A., and Davydov, S.: Snowmelt dominance of dissolved organic carbon in high-latitude watersheds: Implications for characterization and flux of river DOC, Geophys. Res. Lett., 33, L10401, doi:10.1029/2006GL025754, 2006.

Forbes, D. L.: State of the Arctic Coast 2010 - Scientific Review and Outlook, edited by: International Arctic Science Committee (IASC), Land-Ocean Interactions in the Coastal Zone (LOICS), Arctic Monitoring and Assessment Programme (AMAP), International Permafrost Association (IPA), Helmholtz-Zentrum, Geesthacht, Geesthacht, 178 pp., 2011.

French, H. M.: An appraisal of cryostratigraphy in north-west Arctic Canada, Permafr. Periglac. Proc., 9, 297-312, 1998.

Frey, K. E. and Smith, L. C.: Amplified carbon release from vast West Siberian peatlands by 2100, Geophys. Res. Lett., 32, L09401, doi:10.1029/2004g1022025, 2005.

Fritz, M., Wetterich, S., Meyer, H., Schirrmeister, L., Lantuit, H., and Pollard, W. H.: Origin and characteristics of massive ground ice on Herschel Island (western Canadian Arctic) as revealed by stable water isotope and Hydrochemical signatures, Permafr. Periglac. Proc., 22, 26-38, 2011.

Fritz, M., Wetterich, S., Schirrmeister, L., Meyer, H., Lantuit, H., Preusser, F., and Pollard, W. H.: Eastern Beringia and beyond: Late Wisconsinan and Holocene landscape dynamics along the Yukon Coastal Plain, Canada, Palaeogeogr. Palaeoclimatol. Palaeoecol., 319/320, 28-45, 2012.
Gransee, A. and Führs, H.: Magnesium mobility in soils as a challenge for soil and plant analysis, magnesium fertilization and root uptake under adverse growth conditions, Plant Soil, 368, 5-21, 2013.

Grosse, G., Robinson, J. E., Bryant, R., Taylor, M. D., Harper, W., DeMasi, A., Kyker-Snowman, E., Veremeeva, A., Schirrmeister, L., and Harden, J.: Distribution of late Pleistocene ice-rich syngenetic permafrost of the Yedoma Suite in east and central Siberia, Russia, US Geological Survey, Reston, Virginia, USA, 37 pp., 2013.

Günther, F., Overduin, P. P., Sandakov, A. V., Grosse, G., and Grigoriev, M. N.: Short- and long-term thermo-erosion of ice-rich permafrost coasts in the Laptev Sea region, Biogeosciences, 10, 4297-4318, doi:10.5194/bg-10-4297-2013, 2013.

Günther, F., Overduin, P. P., Yakshina, I. A., Opel, T., Baranskaya, A. V., and Grigoriev, M. N.: Observing Muostakh disappear: permafrost thaw subsidence and erosion of a ground-ice-rich island in response to arctic summer warming and sea ice reduction, The Cryosphere, 9, 151-178, doi:10.5194/tc-9-151-2015, 2015.

Guo, L. and Macdonald, R. W.: Source and transport of terrigenous organic matter in the upper Yukon River: Evidence from isotope $(\delta 13 \mathrm{C}, \Delta 14 \mathrm{C}$, and $\delta 15 \mathrm{~N})$ composition of dissolved, colloidal, and particulate phases, Global Biogeochem. Cy., 20, GB2011, doi:10.1029/2005GB002593, 2006.

Guo, L., Ping, C.-L., and Macdonald, R. W.: Mobilization pathways of organic carbon from permafrost to arctic rivers in a changing climate, Geophys. Res. Lett., 34, L13603, doi:10.1029/2007GL030689, 2007.

Harry, D. G., French, H. M., and Pollard, W. H.: Ice wedges and permafrost conditions near King Point, Beaufort Sea coast, Yukon Territory, Paper 85-1A, Geological Survey of Canada, Ottawa, 111-116, 1985.

Holmes, R., McClelland, J., Peterson, B., Tank, S., Bulygina, E., Eglinton, T., Gordeev, V., Gurtovaya, T., Raymond, P., Repeta, D., Staples, R., Striegl, R., Zhulidov, A., and Zimov, S.: Seasonal and annual fluxes of nutrients and organic matter from large rivers to the Arctic Ocean and surrounding seas, Estuar. Coast., 35, 369-382, 2012.

Horita, J., Ueda, A., Mizukami, K., and Takatori, I.: Automatic $\delta D$ and $\delta^{18} \mathrm{O}$ analyses of multi-water samples using $\mathrm{H}_{2}$ - and $\mathrm{CO}_{2-}$ water equilibration methods with a common equilibration set-up, International Journal of Radiation Applications and Instrumentation - Part A, Appl. Radiat. Isotop., 40, 801-805, 1989.

Hubberten, H.-W., Andreev, A., Astakhov, V. I., Demidov, I., Dowdeswell, J. A., Henriksen, M., Hjort, C., Houmark-Nielsen, M., Jakobsson, M., Kuzmina, S., Larsen, E., Lunkka, J. P., Lyså, A., Mangerud, J., Möller, P., Saarnisto, M., Schirrmeister, L., Sher, A. V., Siegert, C., Siegert, M. J., and Svendsen, J. I.: The periglacial climate and environment in northern Eurasia during the Last Glaciation, Quaternary Sci. Rev., 23, 1333-1357, 2004.

Hugelius, G., Tarnocai, C., Broll, G., Canadell, J. G., Kuhry, P., and Swanson, D. K.: The Northern Circumpolar Soil Carbon Database: spatially distributed datasets of soil coverage and soil carbon storage in the northern permafrost regions, Earth Syst. Sci. Data, 5, 3-13, doi:10.5194/essd-5-3-2013, 2013.

Hugelius, G., Strauss, J., Zubrzycki, S., Harden, J. W., Schuur, E. A. G., Ping, C. L., Schirrmeister, L., Grosse, G., Michaelson, G. J., Koven, C. D., O’Donnell, J. A., Elberling, B., Mishra, U., Camill, P., Yu, Z., Palmtag, J., and Kuhry, P.: Improved 
estimates show large circumpolar stocks of permafrost carbon while quantifying substantial uncertainty ranges and identifying remaining data gaps, Biogeosciences Discuss., 11, 4771-4822, doi:10.5194/bgd-11-4771-2014, 2014.

Jolliffe, I. T.: Principal Component Analysis, 2nd Edn., Springer Series in Statistics, Springer, New York, 488 pp., 2002.

Jorgenson, M. T. and Brown, J.: Classification of the Alaskan Beaufort Sea Coast and estimation of carbon and sediment inputs from coastal erosion, Geo.-Mar. Lett., 25, 69-80, 2005.

Kanevskiy, M., Shur, Y., Fortier, D., Jorgenson, M. T., and Stephani, E.: Cryostratigraphy of late Pleistocene syngenetic permafrost (yedoma) in northern Alaska, Itkillik River exposure, Quaternary Res., 75, 584-596, 2011.

Kanevskiy, M., Shur, Y., Jorgenson, M. T., Ping, C. L., Michaelson, G. J., Fortier, D., Stephani, E., Dillon, M., and Tumskoy, V.: Ground ice in the upper permafrost of the Beaufort Sea coast of Alaska, Cold Reg. Sci. Technol., 85, 56-70, 2013.

Kling, G. W., Kipphut, G. W., and Miller, M. C.: Arctic lakes and streams as gas conduits to the atmosphere: implications for tundra carbon budgets, Science, 251, 298-301, 1991.

Kokelj, S. V., Smith, C. A. S., and Burn, C. R.: Physical and chemical characteristics of the active layer and permafrost, Herschel Island, western Arctic Coast, Canada, Permafr. Periglac. Proc., 13, 171-185, 2002.

Lachniet, M. S., Lawson, D. E., and Sloat, A. R.: Revised ${ }^{14} \mathrm{C}$ dating of ice wedge growth in interior Alaska (USA) to MIS 2 reveals cold paleoclimate and carbon recycling in ancient permafrost terrain, Quaternary Res., 78, 217-225, 2012.

Lantuit, H., Rachold, V., Pollard, W. H., Steenhuisen, F., Ødegård, R., and Hubberten, H.-W.: Towards a calculation of organic carbon release from erosion of Arctic coasts using non-fractal coastline datasets, Mar. Geol., 257, 1-10, 2009.

Lantuit, H., Overduin, P., Couture, N., Wetterich, S., Aré, F., Atkinson, D., Brown, J., Cherkashov, G., Drozdov, D., Forbes, D., Graves-Gaylord, A., Grigoriev, M., Hubberten, H.-W., Jordan, J., Jorgenson, T., Ødegård, R., Ogorodov, S., Pollard, W., Rachold, V., Sedenko, S., Solomon, S., Steenhuisen, F., Streletskaya, I., and Vasiliev, A.: The Arctic Coastal Dynamics Database: A New Classification Scheme and Statistics on Arctic Permafrost Coastlines, Estuar. Coast., 35, 383-400, 2012.

Lepš, J. and Šmilauer, P.: Multivariate Analysis of Ecological Data using CANOCO, Cambridge University Press, 2003.

Mackay, J. R.: Glacier ice-thrust features of the Yukon Coast, Geographical Bulletin, 13, 5-21, 1959.

McGuire, A. D., Anderson, L. G., Christensen, T. R., Dallimore, S., Guo, L., Hayes, D. J., Heimann, M., Lorenson, T. D., Macdonald, R. W., and Roulet, N.: Sensitivity of the carbon cycle in the Arctic to climate change, Ecol. Monogr., 79, 523-555, 2009.

Meyer, H., Schönicke, L., Wand, U., Hubberten, H. W., and Friedrichsen, H.: Isotope studies of hydrogen and oxygen in ground ice - Experiences with the equilibration technique, Isotopes in Environmental and Health Studies, 36, 133-149, 2000.

Meyer, H., Dereviagin, A., Siegert, C., Schirrmeister, L., and Hubberten, H.-W.: Paleoclimate reconstruction on Big Lyakhovsky Island, north Siberia - hydrogen and oxygen isotopes in ice wedges, Permafr. Periglac. Proc., 13, 91-105, 2002.

Meyer, H., Yoshikawa, K., Schirrmeister, L., and Andreev, A.: The Vault Creek Tunnel (Fairbanks region, Alaska) - A late Quaternary palaeoenvironmental permafrost record, Ninth Interna- tional Conference on Permafrost (NICOP), Fairbanks, Alaska, June 29-July 3, 2008.

Meyer, H., Schirrmeister, L., Andreev, A., Wagner, D., Hubberten, H.-W., Yoshikawa, K., Bobrov, A., Wetterich, S., Opel, T., Kandiano, E., and Brown, J.: Lateglacial and Holocene isotopic and environmental history of northern coastal Alaska - Results from a buried ice-wedge system at Barrow, Quaternary Sci. Rev., 29, 3720-3735, 2010a.

Meyer, H., Schirrmeister, L., Yoshikawa, K., Opel, T., Wetterich, S., Hubberten, H.-W., and Brown, J.: Permafrost evidence for severe winter cooling during the Younger Dryas in northern Alaska, Geophys. Res. Lett., 37, L03501, doi:10.1029/2009GL041013, 2010 b.

Meyer, H., Opel, T., Laepple, T., Dereviagin, A. Y., Hoffmann, K., and Werner, M.: Long-term winter warming trend in the Siberian Arctic during the mid- to late Holocene, Nature Geosci., 8, 122 125, 2015.

Murton, J. B.: Stratigraphy and palaeoenvironments of Richards Island and the eastern Beaufort Continental Shelf during the last glacial-interglacial cycle, Permafr. Periglac. Proc., 20, 107-125, 2009.

Nørgaard-Pedersen, N., Spielhagen, R. F., Erlenkeuser, H., Grootes, P. M., Heinemeier, J., and Knies, J.: Arctic Ocean during the Last Glacial Maximum: Atlantic and polar domains of surface water mass distribution and ice cover, Paleoceanography, 18, 1063, doi:10.1029/2002PA000781, 2003.

Olefeldt, D. and Roulet, N. T.: Effects of permafrost and hydrology on the composition and transport of dissolved organic carbon in a subarctic peatland complex, J. Geophys. Res., 117, G01005, doi:10.1029/2011jg001819, 2012.

Opel, T., Dereviagin, A. Y., Meyer, H., Schirrmeister, L., and Wetterich, S.: Palaeoclimatic information from stable water isotopes of Holocene ice wedges on the Dmitrii Laptev Strait, northeast Siberia, Russia, Permafr. Periglac. Proc., 22, 84-100, 2011.

Opsahl, S. and Benner, R.: Distribution and cycling of terrigenous dissolved organic matter in the ocean, Nature, 386, 480-482, 1997.

Ping, C.-L., Michaelson, G. J., Guo, L., Jorgenson, M. T., Kanevskiy, M., Shur, Y., Dou, F., and Liang, J.: Soil carbon and material fluxes across the eroding Alaska Beaufort Sea coastline, J. Geophys. Res. Biogeosci., 116, G02004, doi:10.1029/2010JG001588, 2011.

R Core Team: R: A language and environment for statistical computing, R Foundation for Statistical Computing, Vienna, Austria, 2014

Rachold, V., Eicken, H., Gordeev, V. V., Grigoriev, M. N., Hubberten, H. W., Lisitzin, A. P., Shevchenko, V. P., and Schirrmeister, L.: Modern Terrigenous Organic Carbon Input to the Arctic Ocean, in: The Organic Carbon Cycle in the Arctic Ocean, edited by: Stein, R., and MacDonald, R., Springer Berlin Heidelberg, 33-55, 2004.

Rampton, V. N.: Quaternary geology of the Yukon Coastal Plain, Geological Survey of Canada Bulletin 317, Geological Survey of Canada, Ottawa, 49 pp., 1982.

Raymond, P. A., McClelland, J. W., Holmes, R. M., Zhulidov, A. V., Mull, K., Peterson, B. J., Striegl, R. G., Aiken, G. R., and Gurtovaya, T. Y.: Flux and age of dissolved organic carbon exported to the Arctic Ocean: A carbon isotopic study of the 
five largest arctic rivers, Global Biogeochem. Cy., 21, GB4011, doi:10.1029/2007gb002934, 2007.

Schirrmeister, L., Grosse, G., Kunitsky, V., Magens, D., Meyer, H., Dereviagin, A., Kuznetsova, T., Andreev, A., Babiy, O., Kienast, F., Grigoriev, M., Overduin, P. P., and Preusser, F.: Periglacial landscape evolution and environmental changes of Arctic lowland areas for the last 60000 years (western Laptev Sea coast, Cape Mamontov Klyk), Polar Res., 27, 249-272, 2008.

Schirrmeister, L., Grosse, G., Schnelle, M., Fuchs, M., Krbetschek, M., Ulrich, M., Kunitsky, V., Grigoriev, M., Andreev, A., Kienast, F., Meyer, H., Babiy, O., Klimova, I., Bobrov, A., Wetterich, S., and Schwamborn, G.: Late Quaternary paleoenvironmental records from the western Lena Delta, Arctic Siberia, Palaeogeogr. Palaeoclimatol. Palaeoecol., 299, 175-196, 2011 a.

Schirrmeister, L., Grosse, G., Wetterich, S., Overduin, P. P., Strauss, J., Schuur, E. A. G., and Hubberten, H.-W.: Fossil organic matter characteristics in permafrost deposits of the northeast Siberian Arctic, J. Geophys. Res., 116, G00M02, doi:10.1029/2011jg001647, 2011b.

Schirrmeister, L., Kunitsky, V., Grosse, G., Wetterich, S., Meyer, H., Schwamborn, G., Babiy, O., Derevyagin, A., and Siegert, C.: Sedimentary characteristics and origin of the Late Pleistocene Ice Complex on north-east Siberian Arctic coastal lowlands and islands - A review, Quaternary International, 241, 3-25, 2011c.

Schirrmeister, L., Froese, D., Tumskoy, V., and Wetterich, S.: Yedoma: Late Pleistocene Ice-Rich Syngenetic Permafrost of Beringia, in: The Encyclopedia of Quaternary Science, edited by: Elias, S. A., Elsevier, Amsterdam, 542-552, 2013.

Schneider von Deimling, T., Meinshausen, M., Levermann, A., Huber, V., Frieler, K., Lawrence, D. M., and Brovkin, V.: Estimating the near-surface permafrost-carbon feedback on global warming, Biogeosciences, 9, 649-665, doi:10.5194/bg-9-649-2012, 2012.

Schuur, E. A. G. and Abbott, B.: Climate change: High risk of permafrost thaw, Nature, 480, 32-33, 2011.

Schuur, E. A. G., Bockheim, J., Canadell, J. G., Euskirchen, E., Field, C. B., Goryachkin, S. V., Hagemann, S., Kuhry, P., Lafleur, P. M., Lee, H., Mazhitova, G., Nelson, F. E., Rinke, A., Romanovsky, V. E., Shiklomanov, N., Tarnocai, C., Venevsky, S., Vogel, J. G., and Zimov, S. A.: Vulnerability of permafrost carbon to climate change: Implications for the global carbon cycle, BioScience, 58, 701-714, 2008.

Schuur, E. A. G., Vogel, J. G., Crummer, K. G., Lee, H., Sickman, J. O., and Osterkamp, T. E.: The effect of permafrost thaw on old carbon release and net carbon exchange from tundra, Nature, 459, 556-559, 2009.

Schwamborn, G., Rachold, V., and Grigoriev, M. N.: Late Quaternary sedimentation history of the Lena Delta, Quaternary Internat., 89, 119-134, 2002.

Sellmann, P. V. and Brown, J.: Stratigraphy and diagenesis of perennially frozen sediments in the Barrow, Alaska, region, 2nd International Conference on Permafrost, Yakutsk, Russia, 13-28 July 1973, 171-181, 1973.

Shur, Y., French, H. M., Bray, M. T., and Anderson, D. A.: Syngenetic permafrost growth: cryostratigraphic observations from the CRREL tunnel near Fairbanks, Alaska, Permafr. Periglac. Proc., 15, 339-347, 2004.

Strauss, J., Schirrmeister, L., Grosse, G., Wetterich, S., Ulrich, M., Herzschuh, U., and Hubberten, H.-W.: The deep permafrost car- bon pool of the Yedoma region in Siberia and Alaska, Geophys. Res. Lett., 40, GL058088, doi:10.1002/2013GL058088, 2013.

Striegl, R. G., Aiken, G. R., Dornblaser, M. M., Raymond, P. A., and Wickland, K. P.: A decrease in discharge-normalized DOC export by the Yukon River during summer through autumn, Geophys. Res. Lett., 32, L21413, doi:10.1029/2005g1024413, 2005.

Tarnocai, C., Canadell, J. G., Schuur, E. A. G., Kuhry, P., Mazhitova, G., and Zimov, S.: Soil organic carbon pools in the northern circumpolar permafrost region, Global Biogeochem. Cy., 23, GB2023, doi:10.1029/2008gb003327, 2009.

ter Braak, C. J. F. and Smilauer, P.: CANOCO reference manual and CanoDraw for Windows user's guide : software for canonical community ordination (version 4.5), Biometris, Wageningen, 2002.

Ulrich, M., Grosse, G., Strauss, J., and Schirrmeister, L.: Quantifying wedge-ice volumes in Yedoma and thermokarst basin deposits, Permafr. Periglac. Proc., 25, 151-161, 2014.

van Everdingen, R. O.: Multi-language glossary of permafrost and related ground-ice terms, National Snow and Ice Data Center/World Data Center for Glaciology, Boulder, 1998.

Vonk, J. E., Sanchez-Garcia, L., van Dongen, B. E., Alling, V., Kosmach, D., Charkin, A., Semiletov, I. P., Dudarev, O. V., Shakhova, N., Roos, P., Eglinton, T. I., Andersson, A., and Gustafsson, O.: Activation of old carbon by erosion of coastal and subsea permafrost in Arctic Siberia, Nature, 489, 137-140, 2012.

Vonk, J. E., Mann, P. J., Davydov, S., Davydova, A., Spencer, R. G. M., Schade, J., Sobczak, W. V., Zimov, N., Zimov, S., Bulygina, E., Eglinton, T. I., and Holmes, R. M.: High biolability of ancient permafrost carbon upon thaw, Geophys. Res. Lett., 40, 26892693, 2013a.

Vonk, J. E., Mann, P. J., Dowdy, K. L., Davydova, A., Davydov, S. P., Zimov, N., Spencer, R. G. M., Bulygina, E. B., Eglinton, T. I., and Holmes, R. M.: Dissolved organic carbon loss from Yedoma permafrost amplified by ice wedge thaw, Environ. Res. Lett., 8, 035023, doi:10.1088/1748-9326/8/3/035023, 2013 b.

Walter Anthony, K. M., Zimov, S. A., Grosse, G., Jones, M. C., Anthony, P. M., Iii, F. S. C., Finlay, J. C., Mack, M. C., Davydov, S., Frenzel, P., and Frolking, S.: A shift of thermokarst lakes from carbon sources to sinks during the Holocene epoch, Nature, 511, 452-456, 2014.

Wegner, C., Bennett, K.E., de Vernal, A., Forwick, M., Fritz, M., Heikkilä, M., Łacka, M., Lantuit, H., Laska, M., Moskalik, M., O’Regan, M., Pawłowska, J., Promińska, A., Rachold V., Vonk, J. E., and Werner, K.: Variability in transport of terrigenous material on the shelves and the deep Arctic Ocean during the Holocene, Polar Res., in review, 2015.

Wetterich, S., Schirrmeister, L., Andreev, A. A., Pudenz, M., Plessen, B., Meyer, H., and Kunitsky, V. V.: Eemian and Late Glacial/Holocene palaeoenvironmental records from permafrost sequences at the Dmitry Laptev Strait (NE Siberia, Russia), Palaeogeogr. Palaeoclimatol. Palaeoecol., 279, 73-95, 2009.

Wetterich, S., Rudaya, N., Tumskoy, V., Andreev, A. A., Opel, T., Schirrmeister, L., and Meyer, H.: Last Glacial Maximum records in permafrost of the East Siberian Arctic, Quaternary Sci. Rev., 30, 3139-3151, 2011.

Wetterich, S., Tumskoy, V., Rudaya, N., Andreev, A. A., Opel, T., Meyer, H., Schirrmeister, L., and Hüls, M.: Ice Complex forma- 
tion in arctic East Siberia during the MIS3 Interstadial, Quaternary Sci. Rev., 84, 39-55, 2014.

Willerslev, E., Davison, J., Moora, M., Zobel, M., Coissac, E., Edwards, M. E., Lorenzen, E. D., Vestergard, M., Gussarova, G., Haile, J., Craine, J., Gielly, L., Boessenkool, S., Epp, L. S., Pearman, P. B., Cheddadi, R., Murray, D., Brathen, K. A., Yoccoz, N., Binney, H., Cruaud, C., Wincker, P., Goslar, T., Alsos, I. G., Bellemain, E., Brysting, A. K., Elven, R., Sonstebo, J. H., Murton, J., Sher, A., Rasmussen, M., Ronn, R., Mourier, T., Cooper, A., Austin, J., Moller, P., Froese, D., Zazula, G., Pompanon, F., Rioux, D., Niderkorn, V., Tikhonov, A., Savvinov, G., Roberts, R. G., MacPhee, R. D. E., Gilbert, M. T. P., Kjaer, K. H., Orlando, L., Brochmann, C., and Taberlet, P.: Fifty thousand years of Arctic vegetation and megafaunal diet, Nature, 506, 47-51, 2014.
Zhang, T., Barry, R. G., Knowles, K., Heginbottom, J. A., and Brown, J.: Statistics and characteristics of permafrost and ground-ice distribution in the Northern Hemisphere, Polar Geogr., 23, 132-154, 1999.

Zimov, S. A., Davydov, S. P., Zimova, G. M., Davydova, A. I., Schuur, E. A. G., Dutta, K., and Chapin, F. S., III: Permafrost carbon: Stock and decomposability of a globally significant carbon pool, Geophys. Res. Lett., 33, L20502, doi:10.1029/2006gl027484, 2006a.

Zimov, S. A., Schuur, E. A. G., and Chapin, F. S.: Permafrost and the Global Carbon Budget, Science, 312, 1612-1613, $2006 \mathrm{~b}$.

Zuur, A. F., Ieno, E. N., and Smith, G. M.: Analysing Ecological Data, Springer, New York, 2007. 